\title{
FINANGIAL ATTRACTIVENESS OF WOOD PRODUCTION IN SMALLHOLDER PLANTATIONS OF GENTRAL VIETNAM IN THE CONTEXT OF DEVELOPING CARBON MARKETS
}

\author{
Arvola $\mathrm{AM}^{1}$, Ha $\mathrm{HT}^{2}$, Kanninen $\mathbf{M}^{1}$, Malkamäki $\mathrm{A}^{3} \&$ Simola $\mathrm{N}^{4}$ \\ ${ }^{1}$ Viikki Tropical Resources Institute, Latokartanonkaari 7, University of Helsinki, Finland A \\ ${ }^{2}$ University of Agriculture and Forestry, Phung Hung Street 102, Hue University of Agriculture and Forestry, Vietnam \\ ${ }^{3}$ Helsinki Institute of Sustainability Science, Yliopistonkatu 3, University of Helsinki, Finland \\ ${ }^{4}$ Finnish Agri-Agency for Food and Forest Development (FFD), Simonkatu 6, Helsinki, Finland \\ *anne.arvola@helsinki.fi
}

Submitted April 2020; accepted August 2020

\begin{abstract}
In Vietnam, fast-growing Acacia hybrid dominates commercial smallholdings and is largely managed in short rotations for pulpwood. However, increasing demand for logwood implies growing Acacia hybrid in longer rotations. One way of encouraging smallholders to prolong the rotation would be payments for aboveground carbon storage. Thus, this study evaluated the financial attractiveness of shifting from pulpwood to logwood production, with and without hypothetical carbon payments of $\$ 5, \$ 10$ and $\$ 20 \mathrm{tCO}_{2} \mathrm{e} \mathrm{ha} \mathrm{a}^{-1}$. The data were drawn from smallholder interviews, a plantation inventory and a market study. The growth models for a 5-year pulpwood regime and various logwood regimes used for financial modelling were developed in CO2FIX simulation software. With a financially optimal rotation length of 9-10 years, the study finds that growing Acacia hybrid for logwood is much more profitable than growing it for pulpwood. However, due to thinning in logwood regime, a financially optimal logwood regime stores only $15-16 \%$ more carbon than a 5-year pulpwood regime. Consequently, carbon payments at any of the three price levels would not shift the financially optimal rotation length. The study concluded that carbon payments alone are unlikely to be an effective means to encourage smallholders in central Vietnam to prolong the rotation.
\end{abstract}

Keywords: Acacia hybrid, carbon stocks, climate change, CO2FIX, logwood production, sawlog production

\section{INTRODUCTION}

Plantation forests continue to expand globally following an increase in demand for timber products and other forest services (McEwan et al. 2020, Nepal et al. 2019). However, conventional large-scale plantations face resistance due to their limited economic inclusiveness and competition over increasingly scarce land (Malkamäki et al. 2018). This is particularly true for the crowded parts of Asia, where many countries have recently promoted smallholder forestry for economic and environmental benefits (Bull et al. 2006, Midgley et al. 2017).

In Vietnam, $45 \%$ of the circa 4-millionhectare tree plantation area is managed by smallholders with an average plantation size of 1.27 hectares (MARD 2016). The fast-growing clonal Acacia hybrid (Acacia mangium $\times$ Acacia auriculiformis) has been planted extensively in the southern and central provinces of Vietnam and has become one of the main commercial species planted by smallholders (Frey et al. 2018). The smallholder plantations supply short rotation acacia (4-6 years) to the exportoriented chipping industry, but fail to meet the growing demand for logwood that would imply longer rotations (8-10 years). Although Vietnam has become the sixth largest exporter of wood products globally, the domestic demand required importing wood worth $\$ 1.5$ billion in 2017 (Rizzetti et al. 2018). The great demand for logwood, especially legal and traceable, has pushed Vietnam to promote domestic production (Hung et al. 2019).

Previous research suggests that smallholders could gain considerably from growing trees for logwood (Maraseni et al. 2017). Prolonged rotation times can also contribute to climate change mitigation and may provide new income opportunities for smallholders in rapidly developing carbon markets (Hamrick 
\& Gallant 2018, White et al. 2018). Global and regional studies provide insight to the impact of carbon payments on optimal rotation, many of them having fast-growing species in focus (Diaz-Balteiro et al. 2006, West et al. 2019). Also, several analyses of the financial attractiveness of smallholder wood production in Vietnam are available (Frey et al. 2018, Maraseni et al. 2017). However, studies that consider optimal rotation of Acacia hybrid with integrated carbon payments for smallholder plantations in Vietnam are lacking. Emerging local carbon initiatives and potential involvement of smallholders in these schemes in Vietnam indicate a need for locally relevant analyses, providing support for forest planning.

In this study, the investigation intended to breach the gap by using data from central Vietnam to determine growth, biomass and carbon models, which is then employed in financial modelling over a single rotation. To determine financial optimality, common capital budgeting indicators were used. For financial analysis, a hypothetical carbon payment scheme was developed with three different carbon prices. The sensitivity of the findings was tested against a reduction in wood prices and increase in interest rate. After presenting the materials and methods and summarising the analysis, the findings were discussed with respect to their limitations and implications.

\section{MATERIALS AND METHODS}

\section{Growth and biomass modelling}

A basic sample inventory of 25 smallholder plantations was carried out from September to November 2018 to collect data on Acacia hybrid growth and biomass accumulation in central Vietnam. Fifteen of these plantations were located in the province of Thua Thien Hue and ten in the province of Quang Ngai (Figure 1). Plantations were selected from the records of tree growers' association to represent age classes from two to eight years. As the number of plantations in age classes of 6-8 was very small, randomised sampling for these age classes was not possible.

On each plantation, three inventory plots were measured (radius $=6.51$ metres). Most Acacia hybrid plantations were grown for pulpwood, while planting densities were generally high regardless of the management regime. Table 1 provides descriptive information of smallholder Acacia hybrid plantations in central Vietnam.

Total volume of Acacia hybrid trees in the plots was calculated individually for each tree using diameter at breast height (DBH, $\mathrm{cm}$ ) and height $(\mathrm{m})$ of the trees. The estimation was carried out using the model below, developed by the Vietnam Forestry Science Institute (Binh 2003). The resulting volumes of individual trees in the plot were summed together and subsequently converted to per hectare volume estimate.

$$
\begin{aligned}
& \mathrm{V}=10^{-4} \frac{\pi}{4} \mathrm{DBH}^{2} * \mathrm{H}^{*} 0.49 \\
& \mathrm{M}=\mathrm{n} * \mathrm{~V}
\end{aligned}
$$

where $\mathrm{V}$ is the volume of an average tree $\left(\mathrm{m}^{3}\right.$ tree $\left.\mathrm{e}^{-1}\right)$, $\mathrm{DBH}$ is the average diameter at breast height $(\mathrm{cm}), \mathrm{H}$ is the average height $(\mathrm{m}), \mathrm{M}$ is the total volume per hectare $\left(\mathrm{m}^{3} \mathrm{ha}^{-1}\right)$ and $\mathrm{n}$ is the number of stems per hectare (trees ha ${ }^{-1}$ ).

The development of tree volume $\left(\mathrm{m}^{3} \mathrm{ha}^{-1}\right)$ as a function of tree age was calculated using the volume $\left(\mathrm{m}^{3} \mathrm{ha}^{-1}\right)$ that was obtained from the inventory data by equation I, and volume data $\left(\mathrm{m}^{3} \mathrm{ha}^{-1}\right)$ from Sein and Mitlöhner (2011) (Figure 2). A three-parameter Chapman-Richards function was fitted to the data, as below:

$$
\mathrm{V}=\mathrm{a}\left(1-\mathrm{e}^{-\mathrm{bx}}\right)^{\mathrm{c}}
$$

where $\mathrm{V}$ is stand volume $\left(\mathrm{m}^{3} \mathrm{ha}^{-1}\right), \mathrm{x}$ is tree age (years), $\mathrm{a}$ is $261.52, \mathrm{~b}$ is 0.42 and $\mathrm{c}$ is 3.55 .

The aboveground biomass in terms of dry matter (MgDM) and carbon $(\mathrm{MgC})$ were modelled using CO2FIX stand level simulation software (Masera et al. 2003, Schelhaas et al. 2004). In the CO2FIX model, carbon dioxide in the atmosphere flows to the tree biomass through growth and storage of biomass carbon stocks. Carbon accumulated in the biomass is transferred to the soil by litterfall, and transferred to products as raw material through harvests, or to the soil as harvest residues (Schelhaas et al. 2004). The model calculates all carbon fluxes from the production of biomass, decomposition in the soil and decomposition from products. The basic input data for CO2FIX model is the stem volume table over stand age and allocation pattern of biomass growth 


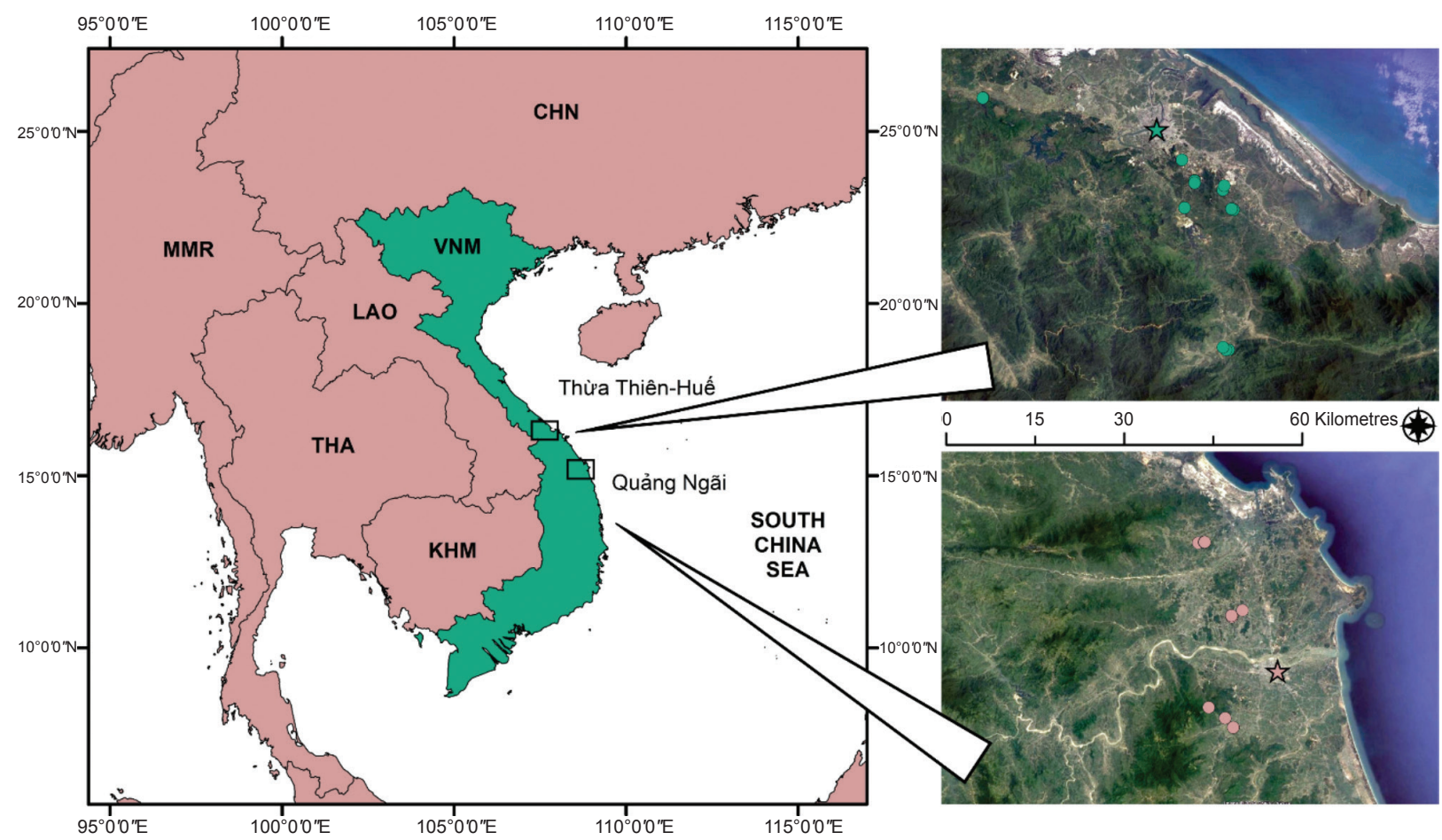

Figure 1 Locations of the measured smallholder plantations in Central Vietnam; points in the satellite images = plantations, stars = regional capital cities; elaboration based on satellite imagery (USGS 2019)

Table 1 Descriptive information for the measured smallholder Acacia hybrid plantations

\begin{tabular}{|c|c|c|c|}
\hline & Mean & Range & STD \\
\hline \multicolumn{4}{|l|}{ Plantations for pulpwood production } \\
\hline Initial planting density (trees ha ${ }^{-1}$ ) & 3,080 & $2,000-10,000$ & 817 \\
\hline Measured tree density (trees ha-1) & 2,744 & $1,975-3,725$ & 610 \\
\hline Age (years) & 3.6 & $1.5-6.0$ & 1.3 \\
\hline Area (ha) & 1.9 & $0.3-7.0$ & 2.0 \\
\hline Tree diameter at breast height $(\mathrm{cm})$ & 7.4 & $4.6-10.3$ & 1.6 \\
\hline Stand volume $\left(\mathrm{m}^{3} \mathrm{ha}^{-1}\right)$ & 68.1 & $14.6-137.4$ & 40.8 \\
\hline Mean annual increment of volume $\left(\mathrm{m}^{3} \mathrm{ha}^{-1}\right.$ year $\left.{ }^{-1}\right)$ & 17.6 & $7.3-30.5$ & 7.1 \\
\hline \multicolumn{4}{|l|}{ Plantations for logwood production } \\
\hline Initial planting density (trees ha ${ }^{-1}$ ) & 2,140 & $1,111-3,333$ & 737 \\
\hline Measured tree density (trees ha- 1 ) & 1,417 & $875-2,900$ & 602 \\
\hline Age (years) & 6.7 & $5.0-8.5$ & 1.2 \\
\hline Area (ha) & 1.8 & $0.5-3.0$ & 0.9 \\
\hline Tree diameter at breast height $(\mathrm{cm})$ & 13.1 & $8.8-15.8$ & 2.1 \\
\hline Stand volume $\left(\mathrm{m}^{3} \mathrm{ha}^{-1}\right)$ & 146.1 & $97.8-202.7$ & 32.9 \\
\hline Mean annual increment of volume $\left(\mathrm{m}^{3} \mathrm{ha}^{-1}\right.$ year $\left.^{-1}\right)$ & 22.1 & $16.3-29.8$ & 5.6 \\
\hline
\end{tabular}


to foliage, branches and roots. These can be parametrised for each forest type, tree species, size class and region (Schelhaas et al. 2004).

The CO2FIX model uses current annual increment of stem volume (CAIVol) $\left(\mathrm{m}^{3} \mathrm{ha}^{-1}\right.$ year $\left.^{-1}\right)$ as the main input, which was derived from equation III. Competition between trees were calculated with a competition factor, i.e. a stand density dependent reduction of the CAIVol (Kanninen et al. 2004). The stem wood biomass $\left(\mathrm{MgDM} \mathrm{ha}^{-1}\right)$ was calculated from the volume using wood specific gravity of $0.45\left(\mathrm{~kg} \mathrm{~m}^{-3}\right)$ (Krisnawati et al. 2011). Foliage and branch biomass were calculated from stem wood biomass using time-dependent biomass expansion factors, and natural mortality of the trees was calculated as an age-dependent fraction of standing biomass (Schelhaas et al. 2004). However, in the current data set, the trees were so young that the natural mortality rate was negligible. Finally, the biomass carbon content $\left(\mathrm{Mg} \mathrm{C} \mathrm{ha}^{-1}\right)$ was calculated using the carbon fraction of dry matter, $0.47\left(\mathrm{Mg} \mathrm{C} \mathrm{MgDM}^{-1}\right)$ (IPCC 2006).

\section{Financial modelling}

The smallholders were interviewed on site to collect information on management practices, costs of plantation management and markets. Information on the costs of various inputs, and prices for pulpwood and logwood, were collected through a market roundtable with regional wood buyers in October 2018. Some costs had to be estimated by the authors based on best available information, including previous studies (Frey et al. 2018, Maraseni et al. 2017). Average establishment and management costs, in terms of inputs and labour, were estimated from the data collected through smallholder interviews and market roundtable (Table 2 ).

Based on the range of stocking densities applied by smallholders, in the current data and previous studies, it is assumed that 2,500 trees ha ${ }^{-1}$ are planted in the pulpwood regime and 1,750 trees ha-1 in the logwood regime (Kunhamu et al. 2011). At the age of one, it is assumed that there is a need to replant 125 trees ha-1 in the pulpwood regime and 100 trees $^{-1}$ in the logwood regime.

Table 2 Prices and costs applicable to smallholder Acacia hybrid plantations

\begin{tabular}{|c|c|c|}
\hline Prices & Unit & $\$$ \\
\hline Pulpwood & $\mathrm{MgDM}$ & $38-42$ \\
\hline Small logwood $(\mathrm{DBH}<16 \mathrm{~cm})$ & $\mathrm{MgDM}$ & $40-50$ \\
\hline Large logwood $(\mathrm{DBH} \geq 16 \mathrm{~cm})$ & MgDM & $50-66$ \\
\hline \multicolumn{3}{|l|}{ Input costs } \\
\hline Seedling, (cuttings type) & 1 seedling & $0.02-0.04$ \\
\hline Seedling (tissue type) & 1 seedling & $0.05-0.10$ \\
\hline Fertiliser ( $1^{\text {st }}$ year $)$ & $300 \mathrm{~g}$ seedling $^{-1}$ & 0.09 \\
\hline Fertiliser ( $2^{\text {nd }}$ year) & 200 g seedling $^{-1}$ & 0.06 \\
\hline \multicolumn{3}{|l|}{ Labour costs } \\
\hline Labour & 1 day $\mathrm{ha}^{-1}$ & 8 \\
\hline Site preparation (manual) & 2 days ha $^{-1}$ & 16 \\
\hline Planting (manual) & 1 seedling & 0.04 \\
\hline Site preparation and planting (machine) & 1 seedling & $0.05-0.06$ \\
\hline Fertilising ( $1^{\text {st }}$ and $2^{\text {nd }}$ year $)$ & 4 days ha $^{-1}$ & 3 \\
\hline Weeding ( $1^{\text {st }}$ year $)$ & 6 days ha $^{-1}$ & 48 \\
\hline Weeding ( $2^{\text {nd }}$ and $3^{\text {rd }}$ year $)$ & 5 days ha $^{-1}$ & 40 \\
\hline Trail management (annual) & 2 days ha $^{-1}$ & 16 \\
\hline Harvesting man & MgDM & $1.6-2.0$ \\
\hline Harvesting team & $\mathrm{MgDM}$ & $4.8-6.0$ \\
\hline Transportation & $\mathrm{MgDM} \mathrm{km}^{-1}$ & $0.4-0.6$ \\
\hline
\end{tabular}

Monetary values in United States dollar (\$) 
The establishment costs for the former are thus higher, but the additional costs for the latter include the costs of thinning (i.e., harvesting) and transportation of thinning products (i.e., pulpwood).

Other assumptions that apply to the financial analysis are as follows: hole digging for tree planting is done using an excavator, the hiring cost of which is included in the planting cost; seedlings are of the cuttings type; fertilising requires four labour days in the first and second year; weeding requires six labour days in the first year and five in the second and third year; trail management requires two labour days every year until final felling; all harvesting, including debranching, peeling and loading, is undertaken by a harvesting team; and pulpwood and logwood are transported to and sold at the factory gate. As regards to transportation costs, sawmills are assumed to be located inland, thus, nearer than export-oriented chipping mills next to the main ports along the coast. Based on information from the market study and fieldwork, the chipping mills and sawmills are assumed to be 25 and 12.5 kilometres away, respectively.

The 5-year pulpwood regime without carbon payments was compared to the logwood regime with and without carbon payments over a single rotation. To evaluate financial optimality, common capital budgeting indicators were used, with net present value (NPV), internal rate of return (IRR) and land expectation value (LEV) for rotations from eight to eleven years. The NPV is the sum of all discounted new revenues (costs subtracted from revenues) associated with a project. The IRR refers to the discount rate for which the NPV of a project is 0 . The LEV is the present value of the projected costs and revenues from an infinite series of identical evenaged rotations, starting initially from bare land. The NPV and LEV are theoretically appropriate indicators of optimality when land is the most constrained input; the IRR when an investor is short of cash or time (Mercer et al. 2014). LEV can also be applied as an indicator of the value of bare land if it is sold today. The IRR must be calculated iteratively by calculating the NPV several times with different interest rates until the resulting NPV is approximately zero. The NPV is calculated as follows:

$$
N P V=-E+\frac{-R\left[(1+i)^{t}-1\right]}{i(1+i)^{t}}+\frac{V_{t}}{(1+i)^{t}}
$$

where NPV is the net present value $\left(\$ h a^{-1}\right), E$ is the initial establishment cost $\left(\$ h a^{-1}\right), R$ the annual management expense $\left(\$ \mathrm{ha}^{-1}\right)$, Vt is the final expected revenue at final felling $\left(\$ \mathrm{ha}^{-1}\right)$ and $i$ is the interest rate. The calculation of LEV is straightforward after calculating the present value of the first rotation and converting it into a future value:

$$
\begin{aligned}
& \mathrm{PV}_{\mathrm{R}_{1}}=-\mathrm{E}+\sum_{\mathrm{t}=1}^{\mathrm{R}-1} \frac{\mathrm{I}_{\mathrm{t}}}{(1+\mathrm{r})^{\mathrm{t}}}+\frac{\mathrm{A}\left[(1+\mathrm{r})^{\mathrm{R}}-1\right]}{\mathrm{r}(1+\mathrm{r})^{\mathrm{R}}}+\frac{\sum_{\mathrm{p}-1}^{\mathrm{a}} \mathrm{P}_{\mathrm{p}} \mathrm{Y}_{\mathrm{p}, \mathrm{R}}-\mathrm{C}_{\mathrm{h}}}{(1+\mathrm{r})^{\mathrm{R}}}(\mathrm{V}) \\
& \mathrm{FV}_{\mathrm{R}_{1}}=(1+\mathrm{r})^{\mathrm{R}} \mathrm{PV}_{\mathrm{R}_{1}} \\
& \mathrm{LEV}=\frac{\mathrm{FV}_{\mathrm{R}_{1}}}{(1+\mathrm{r})^{\mathrm{R}}-1}
\end{aligned}
$$

where PV is the present value of the first rotation $\left(\$ \mathrm{ha}^{-1}\right), \mathrm{R}$ is the length of the rotation (years), $\mathrm{E}$ is the initial establishment cost $\left(\$ \mathrm{ha}^{-1}\right)$, It is the intermediate cost or revenue occurring at a time t larger than 0 but less than $\mathrm{R}\left(\$ \mathrm{ha}^{-1}\right)$, $\mathrm{A}$ is the net cost or revenue from all annual costs and benefits $\left(\$ \mathrm{ha}^{-1}\right), \mathrm{Pp}$ is the price of the product $\mathrm{p}$ (e.g., $\left.\$ \mathrm{MgC}^{-1}\right), \mathrm{Yp}, \mathrm{R}$ is the expected yield of the product $\mathrm{p}$ at age $\mathrm{R}$ (e.g., $\$ \mathrm{MgC}^{-1}$ ), $\mathrm{n}$ is the number of products in the final harvest (e.g., $\left.\mathrm{MgC} \mathrm{ha} \mathrm{C}^{-1}\right)$, Ch is the cost of selling the product $\left(\$ h^{-1}\right), r$ is the interest rate, $\mathrm{FV}$ is the future value $\left(\$ \mathrm{ha}^{-1}\right)$ and LEV stands for the land expectation value $\left(\$ \mathrm{ha}^{-1}\right)$.

The social interest rate in Vietnam has declined from around $12 \%$ a decade ago to around 6\% in 2018 (SBV 2019). In financial models, discount rate reflects the time-bound risks of an investment (e.g., inflation or increasing likelihood of typhoons). Previous studies suggest that smallholders in Vietnam (and elsewhere) are risk averse and apply higher discount rates than those commonly applied in investment analyses (Djanibekov \& Villamor 2017, Frey et al. 2018). Thus, both NPV and LEV were calculated using both rates $(6 \%$ and $12 \%)$ to analyse their sensitivity to an increased level of risk.

Of the various components of aboveground biomass, only stems contributed to the merchantable wood yield. Following Hung et al. (2019), a gradually changing utility ratio of pulpwood, small logwood (DBH $<16 \mathrm{~cm})$, and large logwood $(\mathrm{DBH} \geq 16 \mathrm{~cm})$ were applied to the logwood regime as follows: 50-50-0 in the 8-year 
rotation, 40-30-30 in the 9-year rotation and $30-30-40$ in the 10-year rotation. The carbon stored in aboveground biomass was considered $100 \%$ merchantable. Carbon $(\mathrm{MgC})$ was converted to carbon dioxide equivalents $\left(\mathrm{tCO}_{2} \mathrm{e}\right)$ using the standard conversion factor 3.667.

Merchantable yield of carbon was considered as carbon stored in the pulpwood regime deduced from carbon stored in the logwood regime (i.e., additionality). It was assumed that the buyer is willing to make a prepayment for $30 \%$ of the modelled carbon storage at the time of plantation establishment. The prepayment intends to facilitate cash flow to smallholder and commit the smallholder to store carbon throughout the contract period. It was assumed that the final payment be made at the time of final felling, irrespective of what happens to the land thereafter. This hypothetical contract is temporary and is assumed to expire at the end of the single-rotation commitment period.
The effect of such hypothetical contracts on financial optimality were modelled at three carbon price levels, i.e. $\$ 5, \$ 10$ and $\$ 20 \mathrm{tCO}_{2} \mathrm{e}^{-1}$. The lowest price of $\$ 5+\mathrm{CO}_{2} \mathrm{e}^{-1}$ is close to the early-2018 average voluntary carbon payment in Ecosystem Marketplace (Hamrick \& Gallant 2018). The highest price of $\$ 20 \mathrm{tCO}_{2} \mathrm{e}^{-1}$ is close to the late-2018 average price of a European Emission Allowance (EEX 2019). The actual prices in these periods and market systems have ranged between $\$ 0.1-\$ 70$ and $\$ 10-\$ 28$, respectively. The third option of $\$ 10 \mathrm{tCO}_{2} \mathrm{e}^{-1}$ was used to have three different levels that corresponded to the doubling of carbon price. It was argued that the applied levels were realistic, in the sense that they could be expected to be paid for small-scale carbon forestry in Vietnam.

Further sensitivity analysis was conducted by modelling the effects of $20 \%$ lower wood prices on the profitability and financial optimality of smallholder Acacia hybrid plantations. Such

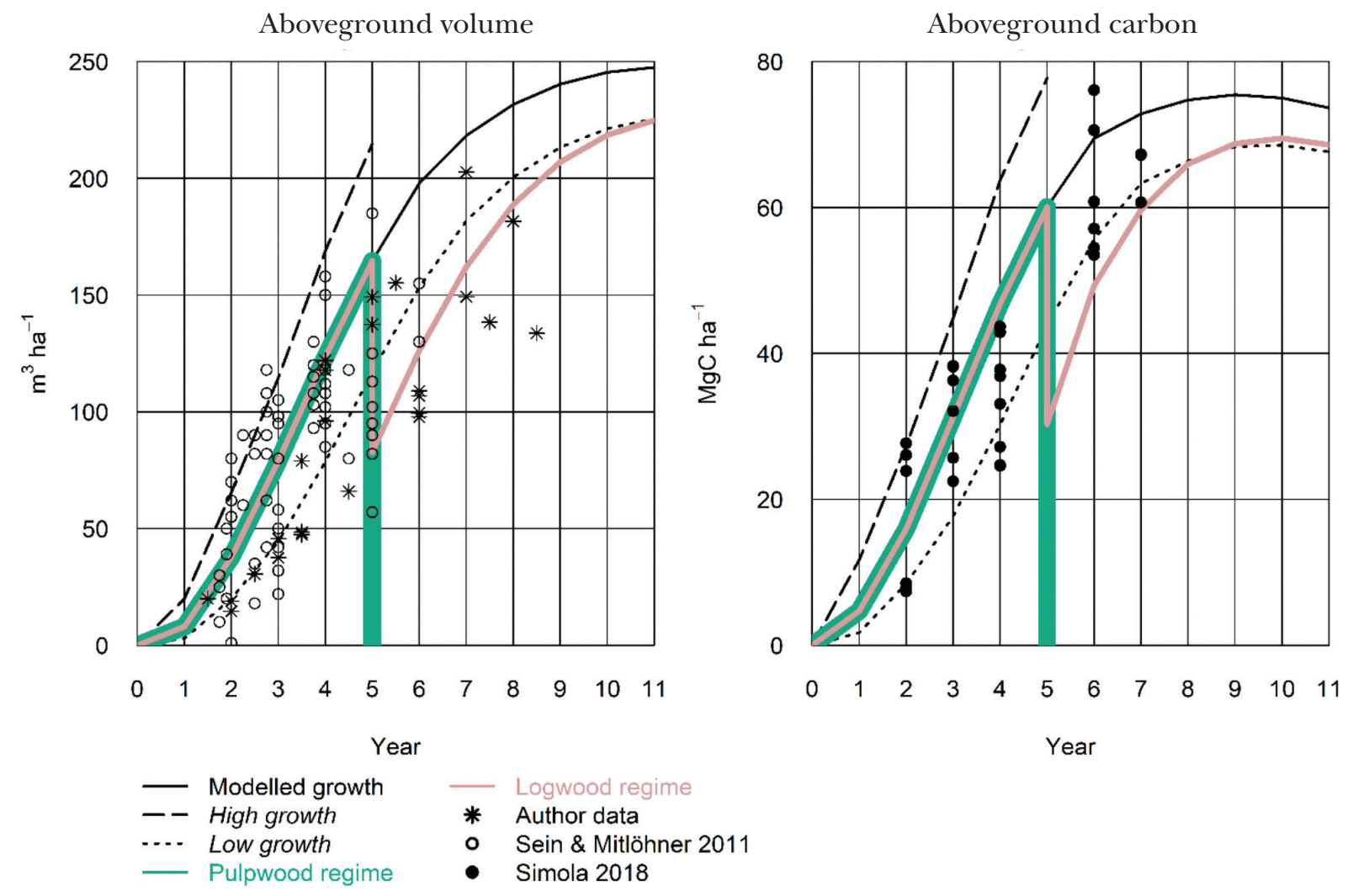

Figure 2 The modelled volume $\left(\mathrm{m}^{3} \mathrm{ha}^{-1}\right)$ (left panel, solid line) and aboveground biomass carbon stock $(\mathrm{Mg} \mathrm{C} \mathrm{ha-1)} \mathrm{(right} \mathrm{panel,} \mathrm{solid} \mathrm{line)} \mathrm{for} \mathrm{the} \mathrm{two} \mathrm{applied} \mathrm{management} \mathrm{regimes} \mathrm{(1)} \mathrm{pulpwood}$ regime - green line, no thinning, rotation length 5 years, and (2) logwood regime - red line, one thinning ( $50 \%$ of basal area) at 5 years, rotation length 11 years; the dashed lines in both panels indicate a "high growth" and "low growth" ranges estimated as $\pm 25 \%$ of the modelled growth levels; data points used for model calibration and validation are marked with dots and crosses 
drops in prices could be caused by a large quantity of timber entering the market at once (e.g., due to a typhoon). All calculations were provided as supplementary material.

\section{RESULTS}

\section{Growth and biomass models}

Figure 2 presents the modelled growth of Acacia hybrid for average site conditions with initial stocking density of 2,200 trees ha ${ }^{-1}$. Also, high growth and low growth ranges were estimated as $\pm 25 \%$ of the modelled growth levels (the former was applied to pulpwood production). Based on the modelled growth, a 5-year pulpwood regime without thinning and a logwood regime up to 11 years with one high-intensity thinning $(-50 \%$ of basal area) at the age of 5 years, was developed. The two regimes were developed based on fieldwork and previous studies (Frey et al. 2018, Maraseni et al. 2017). Growth models and management regimes were also compared with other data sources, including Sein \& Mitlöhner (2011) for volume and Simola (2018) for carbon, indicating satisfactory consistency.

The growth models indicated that there is an important trade-off between maximisation of carbon storage and logwood production. The high growth model, reflecting high initial stocking densities in pulpwood production, would store more aboveground carbon in 5 years $\left(77.8 \mathrm{MgC} \mathrm{ha}^{-1}\right)$ than the logwood regime ever would (carbon maximised at the age of 10 at $69.5 \mathrm{MgC} \mathrm{ha}^{-1}$ ) (Figure 2). This difference is due to the substantially higher amount of carbon stored in branches in the high growth model. As high initial stocking densities are common among the inventoried plantations for pulpwood production (Table 1), the additionality of the logwood regime against the 5-year pulpwood regime can thus be negative in practice. However, in the modelled growth, representative of the average growth of inventoried plantations, the pulpwood regime stored $60.1 \mathrm{MgC} \mathrm{ha}^{-1}$, leaving the logwood regime with a carbon additionality of $9.4 \mathrm{MgC} \mathrm{ha}^{-1}$ (16\%).

\section{Financial analysis}

Tables 3 and 4 outline the results of the financial analysis as growth and cash flow tables for the 5-year pulpwood and 9-year logwood regimes. Table 5 summarises the capital budgeting indicators to assess the financial optimality of smallholder Acacia hybrid plantations in central Vietnam in the context of developing carbon markets, with current and $20 \%$ lower wood prices.

The capital budgeting indicators indicated that the logwood regime outstriped the pulpwood regime in profitability even without any additional carbon payments. Both IRR and LEV at 6\% discount rate indicated that final felling should occur at the age of 9 years. NPV at $6 \%$ discount rate is maximised at the age of 10 years.

Given that the IRRs are generally high, adjusting the interest rate from $6-12 \%$ did not dramatically affect the above findings. As the $12 \%$ interest rate favoured earlier revenue streams, the financially optimal rotation shifts towards the 9-year rotation. In case of a sudden drop in wood prices due to demand or supply shocks, the pulpwood regime would turn into a net negative investment at interest rates that exceed $3.4 \%$. Considering these findings, the logwood regime is also a much more secure (i.e., less sensitive) investment compared with the pulpwood regime. The NPV and LEV of the logwood regime remained positive by a wide margin. Again, the results indicated that the financially optimal rotation age is closer to 9 than 8 or 10 years. As the large logwood becomes available only at the age of 9 , felling too early would be costly.

The introduction of hypothetical carbon payments would simply increase the revenues at the time of final felling. Much of the increases in capital budgeting indicators are due to the hypothetical pre-payment for $30 \%$ of the modelled carbon additionality that is not subject to discounting. Such payments would not be trivial to smallholders in absolute financial terms, but their existence would not alter the financially optimal rotation age either. In strictly economic terms, harnessing carbon payments alone to increase the financial attractiveness of the longer-term investment would thus be both an inefficient and ineffective instrument for encouraging smallholders in central Vietnam to produce logwood.

\section{DISCUSSION}

Based on the findings, growing Acacia hybrid is a highly profitable activity for Vietnamese 
Table 3 Growth and cash flow table for smallholder Acacia hybrid plantation in 5-year pulpwood regime without carbon payments

\begin{tabular}{|c|c|c|c|c|c|c|}
\hline Year & 0 & 1 & 2 & 3 & 4 & 5 \\
\hline Stocking (trees ha-1) & 2,500 & & & & & \\
\hline Replanting (trees ha-1) & & 125 & & & & \\
\hline \multicolumn{7}{|l|}{ Growth in pulpwood regime } \\
\hline Volume $\left(\mathrm{m}^{3}\right)$ & 0 & 8 & 38 & 79 & 124 & 165 \\
\hline Dry matter, stem (MgDM) & 0 & 4 & 17 & 36 & 56 & 75 \\
\hline Dry matter, foliage (MgDM) & 0 & 3 & 4 & 8 & 12 & 18 \\
\hline Dry matter, branches (MgDM) & 0 & 3 & 13 & 24 & 32 & 36 \\
\hline Carbon, stem (MgC) & 0 & 2 & 8 & 17 & 26 & 35 \\
\hline Carbon, foliage (MgC) & 0 & 2 & 2 & 4 & 6 & 8 \\
\hline Carbon, branches (MgC) & 0 & 1 & 6 & 11 & 15 & 17 \\
\hline Carbon dioxide $\left(\mathrm{tCO}_{2} \mathrm{e}\right)$ & 0 & 17 & 58 & 115 & 172 & 220 \\
\hline \multicolumn{7}{|l|}{ Input costs } \\
\hline Seedlings & -78 & -4 & & & & \\
\hline Fertiliser & -222 & -148 & & & & \\
\hline \multicolumn{7}{|l|}{ Labour costs } \\
\hline Planting seedlings & -145 & -7 & & & & \\
\hline Fertilising seedlings & -32 & -32 & & & & \\
\hline Weeding & -48 & -40 & -40 & & & \\
\hline Managing trails & -16 & -16 & -16 & -16 & -16 & \\
\hline Harvesting & & & & & & -405 \\
\hline Transporting & & & & & & -974 \\
\hline \multicolumn{7}{|l|}{ Revenues } \\
\hline Pulpwood sales & & & & & & 2,997 \\
\hline \multicolumn{7}{|l|}{ Cash flow } \\
\hline Without carbon payment & -541 & -247 & -56 & -16 & -16 & 1,618 \\
\hline
\end{tabular}

Monetary values in United States dollar (\$)

smallholders. The applied capital budgeting indicators showed that producing logwood in longer rotations yielded significantly higher returns than a 5-year rotation (pulpwood regime), even without any additional payments for carbon storage. Based on these indicators together with the sensitivity tests, the financially optimal rotation age for logwood production, with and without carbon payments, was 9-10 years. The findings concerning financial attractiveness of growing logwood instead of pulpwood in Vietnam were in line with those of Maraseni et al. (2017a).

Prolonging the rotation obviously becomes more profitable if the hypothetical payments for carbon additionality are realised. However, because of the thinning that occurs in the logwood regime at the age of five, the addition to carbon stocks was only $32-35 \mathrm{tCO}_{2} \mathrm{e}(15-$ $16 \%)$, when comparing the logwood regimes of 9 or 10 years with the 5 -year pulpwood regime $\left(220 \mathrm{tCO}_{2} \mathrm{e}\right)$. As the data of the carbon stocks for an average Acacia hybrid plantation in central Vietnam did not greatly differ from other studies on Acacia mangium plantations, e.g. Heriansyah et al. (2007) for volume and biomass and Kunhamu et al. (2011) for carbon stocks, it was concluded that the findings are robust.

In terms of profitability, the intensity and timing of thinning during the whole rotation period is the key factor (Kanninen et al. 2004, Hung et al. 2019). The thinning operation at the age of 5 years, as applied in the analysis to the logwood regime, brought the stocking 
Table 4 Growth and cash flow table for smallholder Acacia hybrid plantation in 9-year logwood regime with and without carbon payments

\begin{tabular}{|c|c|c|c|c|c|c|c|c|c|c|}
\hline Year & $\mathbf{0}$ & 1 & 2 & 3 & 4 & 5 & 6 & 7 & 8 & 9 \\
\hline $\begin{array}{l}\text { Stocking }(\text { trees ha-1) } \\
\text { Replanting }\left(\text { trees ha }^{-1}\right)\end{array}$ & 1,750 & 100 & & & & & & & & \\
\hline \multicolumn{11}{|l|}{ Growth in logwood regime } \\
\hline Volume $\left(\mathrm{m}^{3}\right)$ & 0 & 8 & 38 & 79 & 124 & 83 & 126 & 162 & 189 & 207 \\
\hline Dry matter, stem (MgDM) & 0 & 4 & 17 & 36 & 56 & 38 & 57 & 74 & 86 & 94 \\
\hline Dry matter, foliage (MgDM) & 0 & 3 & 4 & 8 & 12 & 9 & 24 & 26 & 25 & 21 \\
\hline Dry matter, branches (MgDM) & 0 & 3 & 13 & 24 & 32 & 18 & 24 & 28 & 31 & 32 \\
\hline Carbon, stem (MgC) & 0 & 2 & 8 & 17 & 26 & 18 & 27 & 34 & 40 & 44 \\
\hline Carbon, foliage (MgC) & 0 & 2 & 2 & 4 & 6 & 4 & 11 & 12 & 12 & 10 \\
\hline Carbon, branches (MgC) & 0 & 1 & 6 & 11 & 15 & 9 & 11 & 13 & 14 & 15 \\
\hline Carbon dioxide $\left(\mathrm{tCO}_{2} \mathrm{e}\right)$ & 0 & 17 & 58 & 115 & 172 & 111 & 181 & 219 & 242 & 252 \\
\hline \multicolumn{11}{|l|}{ Input costs } \\
\hline Seedlings & -54 & -3 & & & & & & & & \\
\hline Fertiliser & -155 & -104 & & & & & & & & \\
\hline \multicolumn{11}{|l|}{ Labour costs } \\
\hline Planting seedlings & -102 & -6 & & & & & & & & \\
\hline Fertilising seedlings & -32 & -32 & & & & & & & & \\
\hline Weeding & -48 & -40 & -40 & & & & & & & \\
\hline Managing trails & -16 & -16 & -16 & -16 & -16 & -16 & -16 & -16 & -16 & \\
\hline Harvesting & & & & & & -100 & & & & -509 \\
\hline Transporting & & & & & & -240 & & & & -894 \\
\hline \multicolumn{11}{|l|}{ Revenues } \\
\hline Pulpwood sales & & & & & & 740 & & & & 1,507 \\
\hline Small logwood sales & & & & & & & & & & 1,272 \\
\hline Large logwood sales & & & & & & & & & & 1,639 \\
\hline Carbon payment at $\$ 5$ & 48 & & & & & & & & & 111 \\
\hline Carbon payment at $\$ 10$ & 95 & & & & & & & & & 223 \\
\hline Carbon payment at $\$ 20$ & 191 & & & & & & & & & 445 \\
\hline \multicolumn{11}{|l|}{ Cash flow } \\
\hline Without carbon payment & -407 & -201 & -56 & -16 & -16 & 383 & -16 & -16 & -16 & 3,015 \\
\hline With carbon payment at $\$ 5$ & -359 & -201 & -56 & -16 & -16 & 383 & -16 & -16 & -16 & 3,126 \\
\hline With carbon payment at $\$ 10$ & -312 & -201 & -56 & -16 & -16 & 383 & -16 & -16 & -16 & 3,238 \\
\hline With carbon payment at $\$ 20$ & -216 & -201 & -56 & -16 & -16 & 383 & -16 & -16 & -16 & 3,460 \\
\hline
\end{tabular}

Monetary values in United States dollar (\$)

density to 875 trees ha-1 ${ }^{-1}$ It is important to note that Sein \& Mitlöhner (2011) have proposed that an early thinning at the age of 2-3 years to 450-600 trees $\mathrm{ha}^{-1}$ would be necessary to maximise the proportion of larger-diameter logwood from Vietnamese Acacia hybrid plantations. Recent calculations by Hung et al. (2019) support this argument. However, based on the fieldwork, such a regime was considered very unlikely to be undertaken by smallholders in central Vietnam. Such a regime would also induce an additional reduction in carbon stocks.

The financial analysis excluded possible transaction costs of carbon schemes. These costs and their distribution vary according to the scheme. The type of verification of carbon storage and payments ultimately depend on the type of contract between the buyer and seller (Hamrick \& Gallant 2018). The government of Vietnam is encouraging local transactions by proceeding 
Table 5 Financial optimality of smallholder Acacia hybrid in Central Vietnam with current and reduced $(-20 \%)$ wood prices

\begin{tabular}{|c|c|c|c|c|c|c|}
\hline \multirow{2}{*}{$\begin{array}{l}\text { Management } \\
\text { regime }\end{array}$} & \multirow{2}{*}{$\begin{array}{l}\text { Carbon } \\
\text { payment }\end{array}$} & \multirow{2}{*}{ IRR } & NPV & LEV & NPV & LEV \\
\hline & & & $6 \%$ & $6 \%$ & $12 \%$ & $12 \%$ \\
\hline \multicolumn{7}{|c|}{ Current prices } \\
\hline 5-year pulpwood & $\$ 0$ & $14.6 \%$ & 360 & 2,196 & 91 & 974 \\
\hline \multirow{4}{*}{ 8-year logwood } & $\$ 0$ & $21.7 \%$ & 1,081 & 3,415 & 508 & 1,374 \\
\hline & $\$ 5$ & $23.1 \%$ & 1,160 & 3,596 & 571 & 1,447 \\
\hline & $\$ 10$ & $24.6 \%$ & 1,240 & 3,777 & 633 & 1,520 \\
\hline & $\$ 20$ & $27.8 \%$ & 1,399 & 4,139 & 759 & 1,665 \\
\hline \multirow{4}{*}{ 9-year logwood } & $\$ 0$ & $22.2 \%$ & 1,367 & 3,850 & 631 & 1,497 \\
\hline & $\$ 5$ & $24.0 \%$ & 1,480 & 4,081 & 718 & 1,587 \\
\hline & $\$ 10$ & $25.8 \%$ & 1,594 & 4,311 & 806 & 1,677 \\
\hline & $\$ 20$ & $30.2 \%$ & 1,821 & 4,773 & 982 & 1,856 \\
\hline \multirow{4}{*}{ 10-year logwood } & $\$ 0$ & $21.1 \%$ & 1,450 & 3,775 & 620 & 1,418 \\
\hline & $\$ 5$ & $22.8 \%$ & 1,569 & 3,994 & 711 & 1,500 \\
\hline & $\$ 10$ & $24.6 \%$ & 1,689 & 4,212 & 802 & 1,582 \\
\hline & $\$ 20$ & $28.9 \%$ & 1,927 & 4,649 & 983 & 1,746 \\
\hline \multicolumn{7}{|c|}{ Reduced prices } \\
\hline 5-year pulpwood & $\$ 0$ & $3.4 \%$ & -88 & 424 & -249 & 188 \\
\hline \multirow{4}{*}{ 8-year logwood } & $\$ 0$ & $14.9 \%$ & 512 & 1,936 & 129 & 779 \\
\hline & $\$ 5$ & $16.4 \%$ & 591 & 2,117 & 192 & 852 \\
\hline & $\$ 10$ & $17.9 \%$ & 671 & 2,298 & 254 & 925 \\
\hline & $\$ 20$ & $21.2 \%$ & 830 & 2,661 & 380 & 1,071 \\
\hline \multirow{4}{*}{ 9-year logwood } & $\$ 0$ & $16.3 \%$ & 733 & 2,354 & 228 & 916 \\
\hline & $\$ 5$ & $18.1 \%$ & 847 & 2,585 & 316 & 1,005 \\
\hline & $\$ 10$ & $20.1 \%$ & 960 & 2,816 & 404 & 1,095 \\
\hline & $\$ 20$ & $24.4 \%$ & 1,188 & 3,277 & 579 & 1,274 \\
\hline \multirow{4}{*}{ 10-year logwood } & $\$ 0$ & $15.8 \%$ & 799 & 2,364 & 224 & 888 \\
\hline & $\$ 5$ & $17.6 \%$ & 918 & 2,582 & 315 & 970 \\
\hline & $\$ 10$ & $19.4 \%$ & 1,037 & 2,800 & 406 & 1,052 \\
\hline & $\$ 20$ & $23.6 \%$ & 1,276 & 3,237 & 587 & 1,216 \\
\hline
\end{tabular}

Optimality is where IRR, NPV and LEV are maximised; monetary values in United States dollar (\$); $\mathrm{IRR}=$ internal rate of return, NPV = net present value, $\mathrm{LEV}=$ land expectation value

with integration of carbon sequestration into a national Payment for Forest Environmental Services (PFES) scheme, where PFES transaction costs are shared between the stakeholders (Phan et al. 2017). Significant transaction costs would compromise the financial attractiveness and relevance of carbon schemes for smallholders in central Vietnam. However, prolonging the rotation remains relevant because of its superior profitability as such. Even if only modestly, in most cases it would also increase carbon stocks from their current levels. Such increases can be important for achieving national or regional emission reduction targets.

Despite the prospect of higher returns, a shift to logwood regime is hindered by limited knowledge in forest plantation management, relative ease of growing and trading pulpwood, and due to the small and fragmented land holdings that complicate experimenting with longer-term investments (Rizzetti et al. 2018; Zhunusova et al. 2019). Also, increasing frequency and intensity of climate hazards and other biotic and abiotic risks may decrease 
smallholders' commitment to longer forest rotations. Root-rot and stem wilt/canker are already major problems in Acacia plantations in Indonesia and Malaysia (Irianto et al. 2006, Nambiar et al. 2014), especially on second and third rotation plantations. Signs of their occurrence in Vietnam were also visible during the fieldwork.

Increasing domestic logwood production in Vietnam requires designing mechanisms for reducing or removing factors that currently constrain smallholders from prolonging the rotation age. Majority of the smallholders interviewed for this study indicated their willingness to prolong rotations if there would be feasible insurance schemes or other risk reduction means. In this regard, the government and other parties could provide low-cost loans or grants to fill such liquidity gaps (possibly through PFES). Alternatively, pre-payment arrangements and investments in infrastructure could support the transition to logwood regime. Many smallholders in central Vietnam are also organising themselves in cooperatives, which clearly carries a lot of potential to aggregate larger quantities of wood for sale, share risks and fixed costs, and facilitate negotiations with wood procurers.

As the study is based on a small sample of smallholder Acacia hybrid plantations in central Vietnam, it was not possible to develop perfectly accurate growth models, on which to base the financial models. The financial modelling also relied on a series of assumptions concerning the costs and activities associated with smallholder plantations in central Vietnam. As discussed above, the costs of administering a carbon scheme were not incorporated into the analysis. More research is thus needed to understand the development of biomass in longer rotations and to clarify the overall cost structure and design of possible carbon payments in smallholder plantations. Importantly, a larger field data set covering the variability in site productivity, plantation age and management regimes is needed to build and verify management guidelines for a wider geographical area and for different conditions, e.g., based on a systematic experimental setup (Kanninen et al. 2004).

\section{CONCLUSIONS}

In central Vietnam, smallholders grow Acacia hybrid plantations with high stocking densities to supply pulpwood to chipping mills. Growing Acacia hybrid for logwood in longer rotations turns out to be a much more profitable investment. The financially optimal rotation age for Acacia hybrid plantations was $9-10$ years. Even with generous payments for carbon additionality that follows the shift from pulpwood production to logwood production, the transaction costs associated with carbon schemes could exceed the benefits. However, with the development of policies or schemes to help smallholders to surpass the barriers of making longer-term investments in plantations, the transition to logwood production becomes more likely. Yet, smallholders currently face several constraints, both institutional and environmental, that prevent them from prolonging the rotation. Paying close attention to the assumptions made, our findings carry potential to aid smallholders in central Vietnam, to evaluate their options and to make well-judged decisions concerning their lands. Altogether, producing Acacia hybrid logwood in longer rotations yields significantly higher returns than pulpwood regime with or without carbon payments, and becomes even slightly more profitable if the payments for carbon additionality are realised. Thereby, carbon payments at their present levels may only provide an additional, but not very significant incentive for smallholder logwood production.

\section{ACKNOWLEDGMENTS}

This work was supported by Finnish Agri-Agency for Food and Forest Development (FFD), Helsinki Institute of Sustainability Science (HELSUS) and the Doctoral Programme in Sustainable Use of Renewable Natural Resources of the University of Helsinki (AGFOREE).

\section{REFERENCES}

BINH NT. 2003. Yield Table of Monocultural Acacia Hybrid Plantations. Vietnam Forestry Science Institute, Hanoi.

Bull GQ, Bazett M, Schwab O et al. 2006. Industrial forest plantation subsidies: Impacts and implications. Forest Policy and Economics 9: 13-31.

Diaz-Balteiro L \& Rodriguez LCE. 2006. Optimal rotations on Eucalyptus plantations including carbon sequestration - a comparison of results in Brazil and Spain. Forest Ecology and Management 229: 247-258

Djanibekov U \& Villamor GB. 2017. Market-based instruments for risk-averse farmers: Rubber agroforest conservation in Jambi Province, Indonesia. 
Environment and Development Economics 22: 133-155.

EEX (Europen Emission Allowance). 2019. Market Data: EU Emission Allowances. Primary Market Auction. European Energy Exchange, Leipzig.

Frey GE, Cubbage FW, Ha TTT et al. 2018. Financial Analysis and Comparison of Smallholder Forest and State Forest Enterprise Plantations in Central Vietnam. International Forestry Review 20: 181-198.

Hamrick K \& Gallant M. 2018. Voluntary Carbon Market Insights: 2018 Outlook and First-Quarter Trends. Forest Trends, Washington DC.

Heriansyah I, Miyakuni K, Kato T et al. 2007. Growth characteristics and biomass accumulations of Acacia mangium under different management practices in Indonesia. Journal of Tropical Forest Science 19: 226-235.

Hung TT, Almeida A, Eyles A et Al. 2019. Maximising growth and sawlog production from Acacia hybrid plantations in Vietnam. New Forests 50: 785-804.

IPCC. 2006. Agriculture, Forestry and Other Land Use. Volume 4. IPCC Guidelines for National Greenhouse Gas Inventories. Institute for Global Environmental Strategies, Hayama.

Irianto RSB, Barry K, Hidayati N et al. 2006. Incidence and spatial analysis of root rot of Acacia mangium in Indonesia. Journal of Tropical Forest Science 18: 157-165.

Kanninen M., Perez D, Montero M et al. 2004. Intensity and timing of the first thinning of Tectona grandis plantations in Costa Rica: results of a thinning trial. Forest Ecology and Management 203: 89-99.

Krisnawati H, Kallio MH \& Kanninen M. 2011. Acacia Mangium Willd.: Ecology, Silviculture and Productivity. Center for International Forestry Research, Bogor.

Kunhamu TK, Kumar BM \& Samuel S. 2011. Does tree management affect biomass and soil carbon stocks of Acacia mangium Willd. stands in Kerala. Pp 217-228 in Kumar BM \& Nair PKR (eds) Carbon Sequestration Potential of Agroforestry Systems: Opportunities and Challenges. Springer, Dordrecht.

Malkamäki A, D'amato D, Hogarth NJ et al. 2018. A systematic review of the socio-economic impacts of large-scale tree plantations, worldwide. Global Environmental Change 53: 90-103.

Maraseni TN, Son HL, Cockfield G et al. 2017. Comparing the financial returns from acacia plantations with different plantation densities and rotation ages in Vietnam. Forest Policy and Economics 83: 80-87.

MARD (Ministry of Agriculture and Rural Development). 2016. Announcement of the Forest Status in 2015 (Decision 3158/QD-BNN-TCLN). Ministry of Agriculture and Rural Development, Hanoi.

Masera OR, Garza-Caligaris JF, Kanninen M et al. 2003. Modelling carbon sequestration in afforestation, agroforestry and forest management projects: the CO2FIX Version 2 approach. Ecological Modelling 164: 177-199.
Mcewan A, Marchi E, Spinelli R et al. 2020. Past, present and future of industrial plantation forestry and implication on future timber harvesting technology. Journal of Forestry Research 31: 339-351.

Mercer E, Frey GE \& Cubbage FW. 2014. Economics of Agroforestry. Pp 188-209 in Kant S \& Alavalapati JRR (eds) Handbook of Forest Resource Economics. Earthscan, New York.

Midgley SJ, Stevens PR \& Arnold RJ. 2017. Hidden assets: Asia's smallholder wood resources and their contribution to supply chains of commercial wood. Australian Forestry 80: 10-25.

Nambiar EKS, Harwood G \& Kien ND. 2014. Acacia plantations in Vietnam: research and knowledge application to secure a sustainable future. Southern Forests 77: 1-10.

Nepal P, Korhonen J, Prestemon JP et al. 2019. Projecting global planted forest area developments and the associated impacts on global forest product markets. Journal of Environmental Management 240: 421-430.

Phan T-HD, Brower R, HoAng LP ET AL. 2017. A comparative study of transaction costs of payments for forest ecosystem services in Vietnam. Forest Policy and Economics 80: 141-149.

Rizzetti D, Swanns K, Holden J et al. 2018. Assessing Opportunities for Forest Landscape Restoration in Quang Tri, Vietnam. International Union for Conservation of Nature, Gland.

SBV. 2019. Interest Rate. The State Bank of Vietnam, Hanoi. SchelhaAs MJ, Esch PW, Groen TA et al. 2004. CO2FIX V 3.1 - A Modelling Framework for Quantifying Carbon Sequestration In Forest Ecosystems. Alterra-rapport 1068, Alterra, Wageningen.

Sein CC \& Mitlöhner R. 2011. Acacia Hybrid: Ecology and Silviculture in Vietnam. Center for International Forestry Research, Bogor.

Simola N. 2018. Carbon stocks and sequestration potential of smallholder Acacia hybrid plantations in Hue, Vietnam. Master's thesis. University of Helsinki, Finland.

USGS (United States Geological Survey). 2019. Earth Explorer. United States Geological Survey, Reston, Virginia.

West taP, Wilson C, Vrachioli M et al. 2019. Carbon payments for extended rotations in forest plantations: Conflicting insights from a theoretical model. Ecological Economics 163: 70-76.

White A, Lutz DA, Howarth RB et AL. 2018. Small-scale forestry and carbon offset markets: an empirical study of Vermont Current Use forest landowner willingness to accept carbon credit programs. PLOS ONE 3: e0201967.

Zhunusova E, SEn LTH, Schröder JM et AL. 2019. Smallholder decision-making on sawlog production: the case of Acacia plantation owners in Central Vietnam. Forests 10: 969 . 